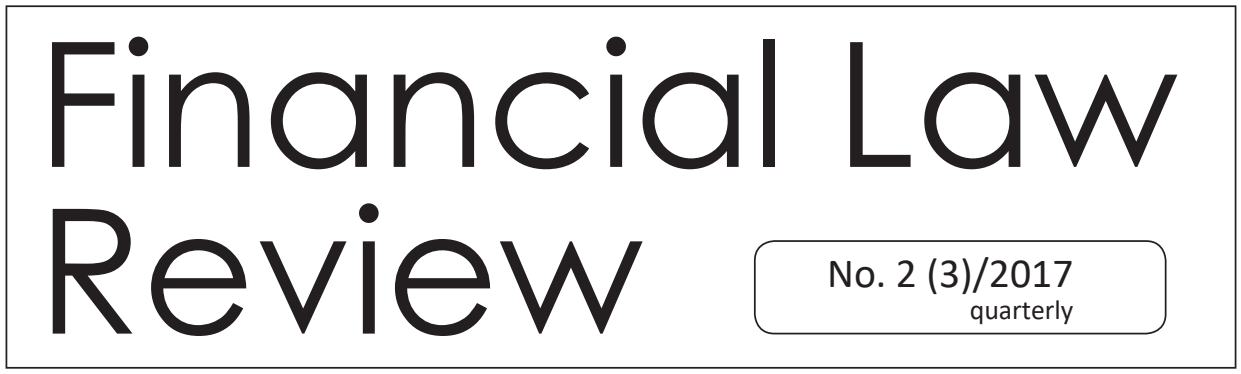

UNIVERSITY OF GDAŃSK • FACULTY OF LAW AND ADMINISTRATION

http://www.ejournals.eu • http://czasopisma.bg.ug.edu.pl

\title{
DIRECTIONS OF ALGORITHM TRANSFORMATION OF BRINGING TO CRIMINAL LIABILITY ON TAX CRIMES AFFAIRS ${ }^{1}$
}

Pastushkova (Любовь Николаевна Пастушкова)

\section{Annotation:}

The present article is devoted to the analysis of last essential change, which has occurred in the criminally-remedial, tax and criminal legislation, with reference to bringing to criminal liability on tax crimes affairs. In this article there is an attempt of finding out how much rational are the respective alterations and what legislative measures it is necessary to undertake in order to make the algorithm of bringing to criminal liability for tax crimes more effective.

The algorithm of bringing to criminal liability represents a set of the remedial actions which are carried out by competent bodies concerning persons, suspected

\footnotetext{
${ }_{1}$ The article is a reprint of the article originally published in System prawnofinansowy: prawo finansowe wobec wyzwan XXI wieku. Law and finance: the financial law towards challenges of the XXI century / J. Gliniecka (red.), CeDeWu, Warszawa 2013
} 
(accused) of crime commission, with a goal to prove the fault of such people in fulfillment of criminal action and thereby, the maintenance of a basic purpose of criminal legal proceedings achievement and the purposes of criminal punishment.

Characteristic sign of such algorithm is necessity of strict and rigorous observance of criminally-remedial legislation norms during fulfillment of all remedial actions, its constitutive, that is caused by action of one of the major, commonly legal in character, principle of criminal legal proceedings - a legality principle (article 7 of the Criminally-remedial code of the Russian Federation). Representing from the functional point of view a set of consecutive remedial actions, the algorithm of bringing to criminal liability on tax crimes affairs is characterized by a number of the specific nuances caused by peculiarities of the criminally-remedial legislation, which regulates a procedure of criminal prosecution on tax crimes affairs, and applied set of norms of the Russian Federation legislation about taxes and gatherings. Short stories of the criminally-remedial legislation have fixed special rules of excitation of a criminal case on tax crimes affairs, have defined the subject who is carrying out criminal prosecution, and also have established the special bases of criminal prosecution termination on affairs of this sort. Let's consider the given short stories of the legislation and follow up the directions of algorithm transformation of bringing to criminal liability on tax crimes affairs.

The first short story, which has caused such transformation, is connected with delegation of responsibilities of criminal prosecution realization on affairs of such sort in the competence of Investigatory committee of the Russian Federation. Abolition of Federal bodies of tax police ${ }^{2}$ in 2003 and delegation of responsibilities on tax crimes investigation, provided by article 198-199.1 of the Criminal code of the Russian Federation, to Internal Affairs Agencies ${ }^{3}$ has led to formation of special structure - Federal Agency of economic and tax crimes.

Since 2003 till January, 1st, 2011 preliminary investigation of tax crimes was carried out by inspectors of the Ministry of Internal Affairs of the Russian Federation,

\footnotetext{
${ }^{2}$ Questions of perfection of the state administration in the Russian Federation: the Decree of the President of the Russian Federation from March, 11th, 2003 №306// Collection of Legislative Acts of the Russian Federation. - 2003. - №12. - article 1099.

3 About modification and additions in some legislative acts of the Russian Federation, recognition of separate acts of the Russian Federation invalid, accordance of separate guarantees to employees of law-enforcement bodies, bodies on control over a turn of narcotics and psychotropic substances and abolished federal bodies of tax police in connection with realization of measures on government perfection: the Federal law from June, 30th, 2003 №86-the Federal law//Union of Right Forces «the Adviser Plus».
} 
but within the limits of the general course on change of legal regulation in sphere of tax criminality, by the Federal law from 12.29.2009 № 383-Federal Law «About modification of part one of the Tax Code of the Russian Federation and separate acts of the Russian Federation» in article 151 of the Criminal code of the Russian Federation, defining the subject investigative jurisdiction of criminal cases, the changes, which essence consists in of affairs about tax crimes in the competence of inspectors of Investigatory committee of the Russian Federation (subitem a, item 1, part 1 of article 151 of the Criminal code of the Russian Federation) have been made. Thus, in hands of inspectors of Investigatory committee of the Russian Federation and heads of investigating bodies (being independent participants of criminal legal proceedings on the prosecution party, possessing by a set of the rights and duties) concentrate serious powers on excitation of criminal cases on tax crimes, realization of preliminary investigation, acceptance of the procedural acts, interfaced to this activity.

The next «package of changes» of criminally-remedial and tax legislation in a part, regulating an order of bringing persons to criminal liability on tax crimes affairs, has been developed and accepted within the limits of the general course of liberalization of the criminal and remedial legislation in relation to the crimes, committed in sphere of economic activities. The Federal law from 12.29.2009 № 383the Federal Law «About modification of part one of the Tax Code of the Russian Federation and separate acts of the Russian Federation» has introduced some short stories:

1) in part 3 of article 32 of the Tax code of the Russian Federation a change has been made, according to which a compulsory condition for a direction of materials to investigating bodies for the decision of a question on criminal case excitation is the decision of taxing authority on attraction of the person to tax responsibility;

2) in part 3 of article 108 of the Tax code of the Russian Federation the basis for attraction of the person to tax responsibility under the taxing authority, the fact of establishment by taxing authorities of infringement of the legislation on taxes and tax collections was named;

3) in articles 198 and 199 of the Criminal code of the Russian Federation notes have been returned, according to which:

The note to article 198 of the Criminal code of the Russian Federation: the person who has committed a crime, provided by the present article, for the first time, is released from a criminal liability if he or she has completely 
paid the sums of a shortage and corresponding fines, and also the penalty sum of the size defined according to the Tax code of the Russian Federation; The note to article 199 of the Criminal code of the Russian Federation: the person, who has committed a crime provided by the present article for the first time, and also according to article 199.1 of the Criminal code of the Russian Federation, is released from a criminal liability if this person or the organization, evasion from payment of taxes and (or) gatherings of which are charged with a given person, completely pays the sums of a shortage and corresponding fines, and also the penalty sum of the size defined according to the Tax code of the Russian Federation;

4) the Criminally-remedial code of the Russian Federation has been added by article 28.1 «The termination of criminal prosecution on affairs about crimes in economic activities sphere», establishing that the court, and also the inspector with the consent of the head of the investigatory body or the investigator with the consent of the public prosecutor stops criminal prosecution concerning the person suspected or accused of commission of a crime, provided by article 198-199.2 of the Criminal code of the Russian Federation, in the presence of the bases provided by articles 24 and 27 the Criminally-remedial code of the Russian Federation or part 76.1 of the Criminal code of the Russian Federation in case if before an appointment of a judicial session the damage caused to budgetary system of the Russian Federation as a result of a crime, is compensated in full. As a matter of fact, in the Criminally-remedial code of the Russian Federation the special basis for the termination of criminal prosecution exactly for tax crimes has been fixed. The norm of part 2 of article 28.1 of the Criminally-remedial code of the Russian Federation concretizes what is understood by damage compensation. Introduction of article 28.1 of the Criminally-remedial code of the Russian Federation of the specified rule has generated a serious divergence of a legal regulation. The matter is that the special basis for releasing from a criminal liability, according to notes to articles 198 and 199 of the Criminal code of the Russian Federation, are compensation of a damage with penalties and fines provided by the law, but on condition that the person has committed a tax crime for the first time, while article 28.1 of the Criminally-remedial code of the Russian Federation provides the unconditional basis for the termination of criminal prosecution in case of compensation of a damage and repayment of fines (penalties) by the person without dependence from a frequency mark. The similar situation, in our opinion, is inadmissible, as, firstly, it creates difficulty of practical 
application in terms of collision of rules, and secondly, reflects the extremely indistinct position of the legislator on the given question. It's not clear what the legislator regards as paramount importance: idea of «the regular tax indulgence», shown in a rule about the termination of criminal prosecution on tax crimes affairs every time, as soon as the person, who made it, will compensate the harm, caused by evasion from payment of taxes, regardless of whether such person committed tax crimes, or the idea of «the unique act of condonation», consisting in the termination of criminal prosecution only in case if the tax crime is committed for the first time. We believe, the last approach realized in the criminal legislation, should find a corresponding standard embodiment in the criminally-remedial legislation as well;

5) introduction of new rules of prejudicial effect of judicial verdicts decided on civil cases and affairs about administrative offences.

An essential change in the Criminally-remedial code of the Russian Federation has been brought by the Federal law from 06.12. 2011 №404-the Federal law. According to entered by the given federal law part 1.1 of article 140 of the Criminally-remedial code of the Russian Federation, a unique occasion to criminal case excitation about the crimes provided by articles 198-199.2 of the criminal code of the Russian Federation (tax crimes), only those materials serve which are directed by tax departments according to the legislation on taxes and tax collections for the decision of a criminal case excitation question. Thus, the legislator somewhat has deduced affairs about tax crimes from under action of the general rules of criminal case excitation. The specified changes, in our opinion, have been caused by following requirements:

1) first of all, the establishment of a unique occasion to criminal case excitation on a tax crime is connected with the account of specificity of such criminal acts which are unevident acts, more often made by intellectual forgery of corresponding documents. Probably, the legislator started with the idea that revealing of the facts of such crimes fulfillment is most effectively carried out by results of specialized checks of competent bodies;

2) by similar rule the legislator aspired to completely exclude such negative practice, taking place to be in the past when the tax bearer (the tax agent) completely paid all sum of the tax, and also penalties and a fine, on request of tax department, and, hence, on norms of tax laws, this fact excluded transfer of materials by corresponding bodies to investigating bodies for the decision of a question on criminal case excitation, however, criminal case excitation on this fact 
could follow, if investigating bodies have the information on the committed act, which is received from other sources (operational entities, for example).

At the moment the order of materials transfer by taxing authorities to the investigation is established in part 3 of article 32 of the Tax code of the Russian Federation: if within two months from the date of the term efflux of requirement execution about tax payment, directed on the basis of the decision on bringing to responsibility for fulfillment of a tax offence, the tax bearer has not paid the sums of the shortage specified in the given requirement in full, the size of which allows to assume the fact of fulfillment of the tax laws infringement, containing signs of a crime of corresponding fines and penalties, tax departments are obliged within 10 days from the date of revealing of the specified circumstances to direct materials to the investigating bodies, authorized to make preliminary investigation on criminal cases about the crimes provided by article198-199.2 of the Criminal code of the Russian Federation, for the decision of a question on criminal case excitation.

According to part 3 of article 108 of the Tax code of the Russian Federation, the basis for bringing of the person to liability of infringement of the legislation on taxes and tax collections can be only the fact of an offence, established by the decision of tax authorities, taken out in an established order by Tax code of the Russian Federation, and which has come into force. The special attention is deserved by necessity of a notation in the act of documentary confirmed facts of infringement of the legislation on the taxes and tax collections, revealed during realization of check, or record about absence of those.

The logic of the legislator who has established such rules, is clear: considering, that tax crimes, as was already mentioned, are characterized by implicit expression of the fact of fulfillment, criminal case excitation is justified only when tax authorities during carrying out the check will elicit the fact of infringement of tax laws (tax non-payment, default of a duty of the tax agent) on the basis of an all-round estimation of materials of such check, and the guilty person will refuse to pay the due sum of the underpaid tax, fines and penalties, within the prescribed time limit, thus the offence will fall under the structure established by the Criminal code of the Russian Federation. The tax bearer (the tax agent), made a tax offence, will have a possibility of protection of the rights by the appeal of the decision of tax authorities about bringing to account for fulfillment of a tax offence administratively. Probably, from a position of the legislator, the similar mechanism of transfer of materials from tax authorities to investigatory for the decision 
of a question on excitation of criminal case upon tax laws infringement will allow if not to exclude at all, at least, to reduce quantity of the illegal and unreasonably raised criminal cases suddenly.

Thus, we believe, the given rules about criminal case excitation about tax crimes cannot be regarded as absolutely proved and that is why admissible as well.

Tax authorities are aimed, mainly, at control of execution of a tax duty legally; their methods of activity are not adapted to reveal the facts of tax crimes. And thereupon it seems quite clear that tax crimes still remain highly latent. We believe it is necessary to return possibility of excitation of criminal cases on tax crimes on the basis of such occasions, as messages on the crime committed or being prepared for fulfillment, received from bodies, carrying out operatively-search activity. Similar change will raise probability of revealing the facts of a tax crime fulfillment, which can remain unnoticed by tax authorities. In order to make the decision on criminal case excitation proved if a cause to excitation is the message from the bodies which are carrying out operatively-search activity, in our opinion, it is necessary to impose a duty to appoint checks on inspectors, with the aim of acknowledgement of the message of the authorities which are carrying out operatively-search activity, on the fact of fulfillment of the tax crime, carrying out of which it should be imposed on employees of the Federal tax service of the Russian Federation.

To avoid possibility of excitation of criminal case concerning the person who has paid the tax and other obligatory sums to payment on request of tax authorities (and similar incidents repeatedly took place in practice of previous years), it is necessary to establish an inspector's duty before the decision of a question on criminal case excitation on a tax crime, to direct inquiry to tax authorities about an establishment of the fact of payment or non-payment of the demanded sum.

That circumstance that the only reason to excitation of criminal cases on tax crimes is granting of materials by tax departments for the decision of a question on criminal case excitation, excludes carrying out such pre-investigative actions, as documentary checks and audits. It forms one of the features of proving in a stage of excitation of criminal case concerning a tax crime. While on any criminal cases carrying out of checks and audits (article 80 of the Criminally-remedial code the Russian Federation) acts as the major means of an establishment of the circumstances, testifying commission of a crime, the given materials of tax checks already comprise data on the fact of a tax crime. In that case the inspector can be 
limited by checking of observance by tax authorities of tax laws norms at drawing up an act of tax check and its conducting.

Directly an order of investigatory actions procedure on affairs about tax crimes, an order of an arraignment to the person who has committed a tax crime, procedure of drawing up and confirmation of indictment, excitation of the public prosecution of the person in fulfillment of a tax crime, and also other rules, connected with bringing to criminal liability on affairs about tax crimes, remained without changes.

Thus, the basic directions of algorithm transformation of bringing to criminal liability on tax crimes affairs are:

1) attaching of the exclusive competence of criminal prosecution realization on affairs of such sort to inspectors of the Investigation Committee of the Russian Federation;

2) an establishment of the only reason for criminal case excitation on tax crimes affairs;

3) a regulation of an order of criminal cases excitation on tax crimes affairs and an establishment of the special bases for the termination of criminal prosecution on such affairs.

All the legislative changes, which are analyzed above, were realized within the limits of the general course of liberalization of the legislation with reference to criminality counteraction in economic sphere. However some legislative decisions, which were considered in the present article, do not look justified and proved enough, hence, relations in this field of legislation need the further transformations.

\section{Reference:}

1. The Tax code of the Russian Federation. Part one from July, 31st, 1998 №146-the Federal law: accepted by the State Duma of the Federal assembly of the Russian Federation on July, 16th, 1998: approved by the Federation Council of the Federal assembly of the Russian Federation on July, 17th, 1998// Rossiiskaya Gazeta - 1998. on August, 6th. - №148-149. Collection of Legislative Acts of the Russian Federation. - 1998. - №31. - Article 3824.

2. The Criminally-remedial code of the Russian Federation from December, 18th, 2001 №174-the Federal law: accepted by the State Duma of the Federation Council of the Russian Federation on November, 22nd, 2001: approved by the Federal assembly of the Russian Federation on December, 5th, 2001// Rossiiskaya Gazeta - 2001. on December, 22nd. - №249. Collection of Legislative Acts of the Russian Federation. - 2001. - №52 (part 1). - Article 4921. 
3. About modification of a part one of the Tax code of the Russian Federation and separate legislative acts of the Russian Federation: the Federal law from December, 29th, 2009 № 383-the Federal law: accepted by the State Duma of the Federation Council of the Russian Federation on December, 23rd, 2009: approved by the Federal assembly of the Russian Federation on December, 25th, 2009// Rossiiskaya Gazeta - 2009. on December, 31st. - №255. Collection of Legislative Acts of the Russian Federation. - 2010. - №1. - Article 4.

4. About modification of the Code of the Russian Federation about administrative offences: the Federal law from December, 6th, 2011 № 404-the Federal law: accepted by the State Duma of the Federation Council of the Russian Federation on November, 22nd, 2011: approved by the Federal assembly of the Russian Federation on November, 29th, 2011// Parlamentskaya Gazeta - 2001. - on December, 9-15th. - №54. Rossiiskaya Gazeta - 2011. - on December, 10th. - №278. Collection of Legislative Acts of the Russian Federation. - 2011. - №50. - Article 7346. 